\title{
PANENSKÝ KLÁŠTER V DOUBRAVNÍKU
}

\section{PAVEL STANĚK}

Abstrakt: Přispěvek se zabývá podobou středověkého kláštera v Doubravníku, která společně s jeho lokalizací nebyla až do výzkumu z let 2011-2013 známa. Na základě nově zjištěných skutečností a s využitím staršich prací zabývajícich se podobou církevního areálu byla rekonstruována nejpravděpodobnějši verze jeho půdorysného řě̌eni. Rozborem ziskané keramiky a pozorovaných stratigrafických vztahů byl učiněn pokus o stanovení stavebního vývoje.

Klíčová slova: Doubravnik - keramika - klášter - stavební vývoj-vlastnický kostel.

\section{The Augustinian Convent in Doubravnik}

Abstract: This contribution discusses the building form of the medieval convent in Doubravnik that, together with its exact location, was not known until research in 2011-2013. On the basis of new information and with the use of the results of earlier research into the form of the complex, the most probable version of its ground plan was drawn up. Analyses of pottery and stratigraphic relations were employed to determine the building development of the convent.

Key words: Doubravnik - pottery - convent-building development-affiliated church.

K historii doubravnického kláštera existuje relativně dostatečné množství dochovaných listin. I přesto zůstává značný počet otázek nezodpovězených, či s nejistým řešením. Umístění kláštera a dispozice klášterních budov byly do nedávné doby jedněmi z těchto otázek. Částečnou odpověd' na ně poskytly až výzkumy prováděné společností Archaia Brno, o. p. s., v letech 2011 až 2013 v okolí goticko-renesančního chrámu Povýšení sv. Kříže (obr. 1, 2).

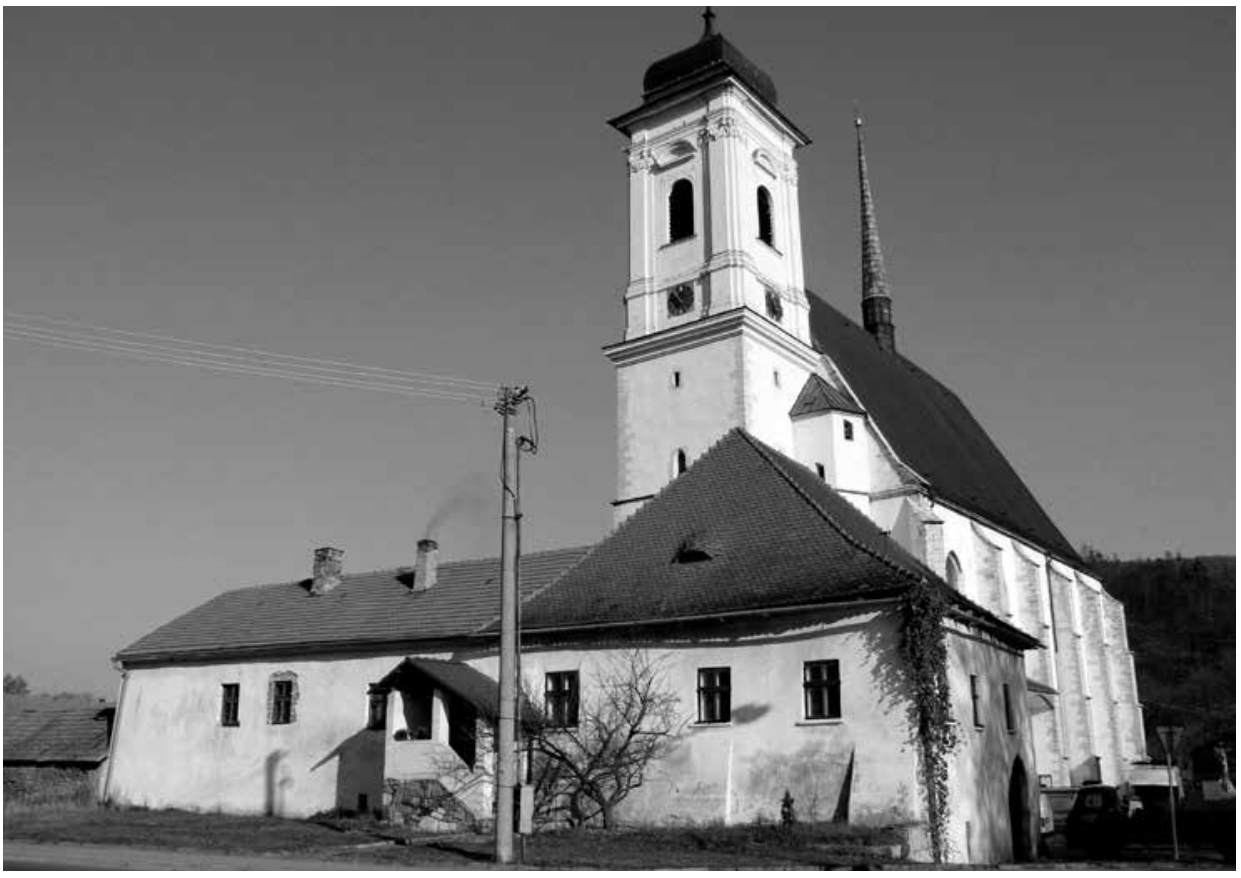

Obr. 1. Doubravník, kostel Povýšení sv. Kříže s domem čp. 35, pravděpodobným proboštstvím někdejšího kláštera. Foto archiv Archaia Brno, o.p.s.

Abb. 1. Doubravník, Kreuzerhöhungskirche mit Haus Konskriptions-Nr. 35, wahrscheinlich die Propstei des ehemaligen Klosters. Foto Archiv der gemeinnützigen Gesellschaft Archaia Brno. 


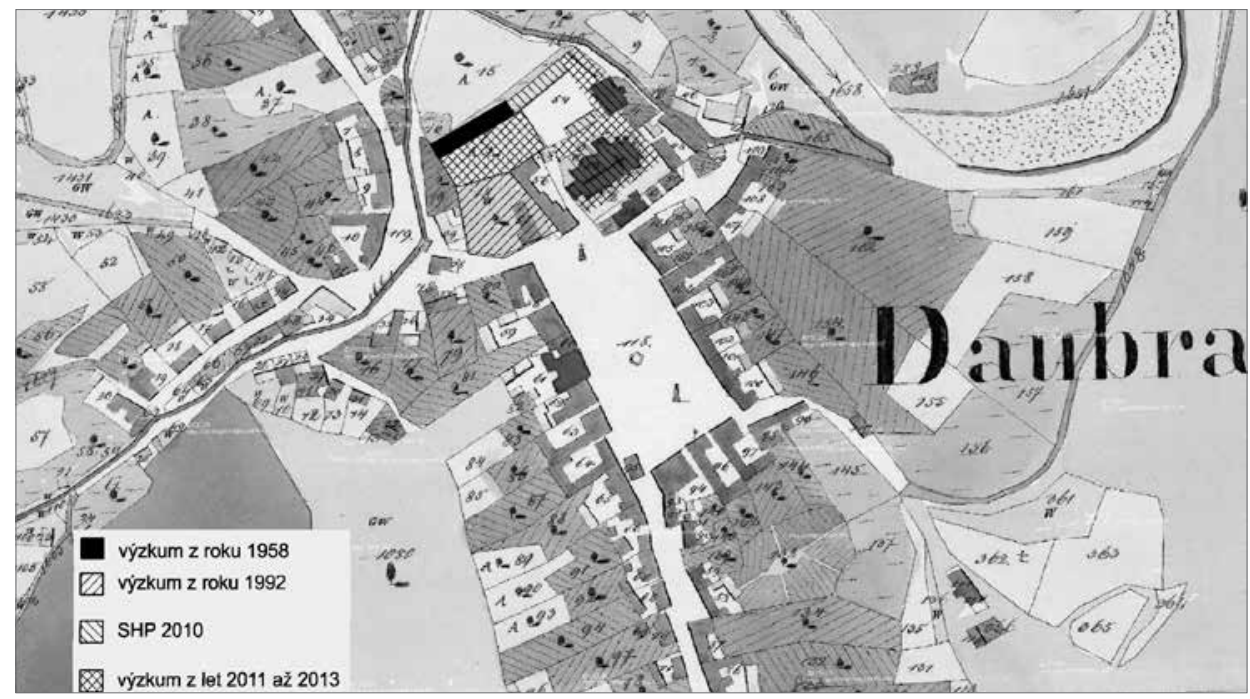

Obr. 2. Obec Doubravník na císařském otisku stabilního katastru z roku $1826 \mathrm{~s}$ vyznačenými výzkumy dotýkajícími se církevního areálu.

Abb. 2. Gemeinde Doubravník auf einem kaiserlichen Abdruck des Stabilen Katasters aus dem Jahr 1826 mit eingezeichneten, das kirchliche Areal betreffenden Grabungen.

\section{Stručné dějiny kláštera}

K roku 1208 se hlásí středověké falzum, které nás informuje o směně majetků mezi Štěpánem z Medlova a olomouckým biskupem Robertem (CDM II, 49-50 č. 41; CDB II, 73-74 č. 78; Vodička 1951, 13). Štěpán z Medlova byl zakladatelem rodové moci pánů z Medlova, později známých pod predikátem z Pernštejna, na horním toku řeky Svratky (k nejstarším dějinám genealogie pánů z Medlova: Sedláček 1992; 1995a; Plaček 1995). Mezi Štěpánovy významné počiny patřilo založení kláštera $v$ centru doubravnického újezdu, k němuž došlo na sklonku jeho života. $\mathrm{K}$ důvodům fundátorské aktivity tak vedle prezentace rodové moci a reprezentativní rodové hrobky mohla patřit snaha po odčinění spáchaných hříchů a projev kajícného pokání (CDB III/1, 147-149 č. 119, 232-233 č. 186; RBM I, 442 č. 950; Sedláček 1992, poznámka 33; Jan 1994, 19; Borovský 2003, 17). Za nejpravděpodobnější dobu vzniku konventu v Doubravníku se dnes pokládá rozmezí let 1228-1231. Vychází se z nejstarší pravé listiny z roku 1231, kde se hovoří o klášteru svatého Františka. Na základě patrocinia se odvozuje nejstarší možný vznik kláštera, který musel následovat až po svatořečení serafínského světce 16. července 1228 (Vodička 1951, 46-47; Sedláček 1992, 41; Jan 1994, 19; Doležel 1998, 321). Klášterní komunitu měly tvořit Bohu zasvěcené ženy. O jejich přesnější řádové příslušnosti se mezi historiky především v průběhu 90. let minulého století vedla hojná diskuse. Dochované písemné prameny nám nedovolují jednoznačné určení, a tak se uvažuje o prŕśslušnicích řádu augustiniánek kanovnic (Jan 1994; 1995), premonstrátek (Sedláček 1992, 41; 1995) či sekulárních kanovnic (poprvé Charouz 1995). Jako o sekulárních kanovnicích s počátečním ovlivněním františkánskou spiritualitou hovoří o doubravnickém konventu Jiří Doležel (1998, 321; Foltýn et al. 2005, 285).

Sám klášter existoval dvě staletí a byl úzce provázán s osudy zakladatelského rodu (Štarha 2003, 31-51; Sadílek 2008, 63-90). Jeho příslušnicemi se stávaly nejčastěji nezaopatřené členky zakladatelského rodu a šlechtických rodů z okolí (Charouz 1995, 371). Značnou část doby trvání konventu ho páni z Medlova a posléze z Pernštejna ochraňovali a obdarovávali pozemky. Po obratu ve smýšlení v souvislosti se změnami, které přineslo husitské hnutí, se stala př́má závislost na rodu Pernštejnů pro klášter zničující. Jan z Pernštejna na podporu své válečné družiny během husitských válek rozdal klášterní pozemky. Po obnově zemského soudu roku 1436 sice spor 
o zcizené pozemky vyhrála abatyše Eliška, ale faktické nápravy se nedočkala. Oproti původnímu předpokladu, že klášter byl zničen husity (Wolny 1837, 310; Oharek 1923, 212; Mazáč-Bukal 1972, 97), je pravděpodobnější, že za zánikem stojí ekonomické problémy, se kterými se konvent nedokázal vypořádat (Doležel 1998, 323).

\section{Hledání „zmizelého“ kláštera}

Mezi další otázky spjaté s klášterem patřila lokalizace a podoba samotných budov konventu.

O vzhledu klášterního komplexu se do určité míry dozvídáme z písemných pramenů (Doležel 1998, 324-325). Kromě konventního kostela je v nich zmínka o sakristii (CDM XII, 266-267 č. 286), kde byly uschovány klášterní písemnosti společně s písemnostmi okolní šlechty. Z dalších známých př́íslušenství je vysloveně zmiňováno dormitorium (CDM IX, 20 č. 26) a komora kláštera. Nepř́ímo jsme k roku 1414 informováni o existenci školy, která se předpokládá na základě zmínky o žácích rozeznívajících zvony. K vybavení kláštera patřil dále špitál, o kterém se k roku 1378 dozvídáme z donace abatyše Kláry a její sestry Anežky. Nacházel se v Doubravníku i po zániku konventu až do počátku 16. století (Doležel 1998, 324-325; Sadílek 2010, 16).

Místní tradice spojovala dům čp. 35 s proboštstvím (Sadílek 2008, 80). Tento predpoklad se, na základě uskutečněných stavebně historických výzkumů a dalšího bádání, zdá být opodstatněný. V jeho blízkosti se pak měl nacházet klášter. Místní historik Leopold Mazáč naproti tomu konvent umistoval do prostoru domů čp. 25 a 26, které obsahovaly staré architektonické články a pod nimiž se nacházela rozsáhlá kamenná sklepení (Mazáč-Bukal 1972, 19-20). Podle pozorování Jiřího Doležela a Marty Procházkové by však uvedená zástavba měla pocházet až z 15. či 16. století (Doležel 1996, 71).

Nejnověji byl středověký klášter umistován do prostoru severně od kostela Povýšení sv. Kříže. Vycházelo se především ze zjištění učiněných geofyzikálním průzkumem z roku 1992 (Hašek-Unger 1994, 38-39). Do př́ípadné spojitosti s klášterem byly dávány i sklepní prostory nacházející se západně od fary (Sadílek 2008, 80), které byly ovšem dalším zkoumáním kladeny až do 16. století (Sadílek 2010, 77-78). Vzhledem k obecnému přiklonění se k variantě přítomnosti sekulárních kanovnic se následně uvažovalo o volném uspořádání budov (Sadílek 2008, 70). Nemusela se zde tak vyskytovat klášterní dispozice vycházející z ideální podoby kláštera, která byla rámcově dodržována většinou středověkých klášterů (Zettler 2006, 50-51).

Archeologickými výzkumy se do roku 2011 nepodařilo architekturu související s místním konventem zachytit. Dokumentovány byly pouze jednotlivé stavební články použité druhotně při výstavbě kamenné zástavby městečka, které se nejpočetněji vyskytují u budov pocházejících z 15. a 16. století (Novotný 1958, 99-100; Doležel 1996, 70-71; 1998, 329).

Širší zázemí kláštera pak bylo pozorováno při výzkumu z roku 1992 pod zbořeným domem čp. 36 a přilehlými parcelami. Dokumentované situace byly interpretovány jako výrobní areál ze 13. století sloužící klášteru. V závěru tohoto století pak výrobní aktivity ustaly. Po následující století a půl mohl sloužit sledovaný prostor jako zahrada či sad (Doležel 1996, 69; 1998, 332).

V průběhu záchranného archeologického výzkumu v roce 1992 došlo k pokusu o podchycení starší podoby sakrálního areálu pomocí geofyzikálního měření s využitím metody DEMP. Interpretace naměřených izolinií měla dle autorů průzkumu Vladimíra Haška a Josefa Ungera zachytit starší kostel, který byl plně pohlcen novostavbou goticko-renesančního chrámu. Podoba původního konventního kostela byla klasifikována jako jednolodní stavba s obdélným presbytářem. Velikost kostela měla činit 20-22×11-13 m. Na východě navazoval mírně obdélný presbytář o velikosti $9,2 \times 5,3 \mathrm{~m}$. Šířka zdiva byla okolo $1 \mathrm{~m}$. Určitý předpoklad pak ještě poukazoval na existenci obdélné konstrukce na západě, kde se mohla nacházet věž či nějaká předsín̆ (Hašek-Unger 1994, 32-33 a 38-39; Hašek-Unger 2001, 98). Zda podoba klášterního kostela odpovídala naměřeným skutečnostem z roku 1992, zůstává prozatím nezodpovězeno. Jediná zed', která byla na základě geomagnetického měření rozpoznána mimo prostor kostela, představovala ohradní zídku. Zídka byla považována za potvrzení správnosti měření, nebot' byla vyobrazena i na mapě stabilního katastru z roku 1826 (Doležel 1998, 330). Provedeným průzkumem v letech 


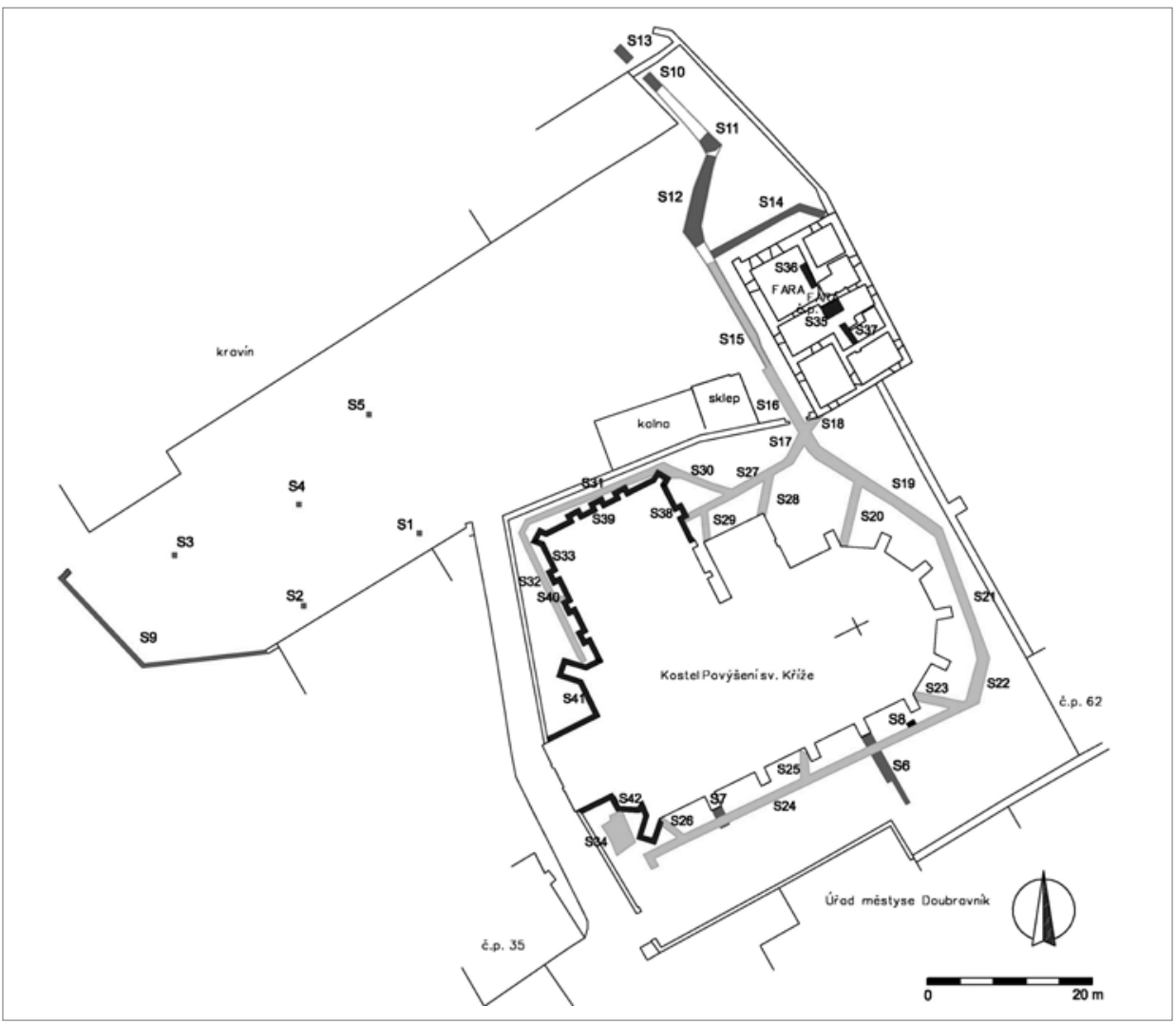

Obr. 3. Přehled sond dokumentovaných v rámci předstihového výzkumu a záchranného výzkumu v letech 2011 až 2013.

Abb. 3. Übersicht der im Rahmen einer Vorgrabung und der von 2011 bis 2013 erfolgten Rettungsgrabung dokumentierten Sondierschnitte.

2011 a 2012 však zídka zachycena nebyla. V uvedené trase bylo zaznamenáno pouze uzemnění hromosvodu.

Další zpřesnění podoby církevního areálu přineslo stavebně historické zkoumání Jaroslava Sadílka (2010). Jeho pozorování zásadně přehodnotila pohled na vznik fary, která byla doposud považována za barokní novostavbu. Především na základě detailního zaměření, ve kterém vynikly rozdílné šíře zdiv, stanovil jednotlivé etapy výstavby farní budovy, které by mohly dle jeho závěrů mít původ již na počátku 13. století. Dataci opírá o pozorování zazděného okenního otvoru ve východní zdi suterénu, který by za určitých předpokladů měl odpovídat románskému oknu z první poloviny 13. století. Popisuje jej však jako „oboustranně výrazně špaletované uprostřed síly zdi opatřené úzkým kamenným ostěním hrubšího provedeni bez zřetelné profilace“ (Sadílek 2010, 104). Postrádáme tudíž citlivější chronologický prvek, který by tak ranou dataci jednoznačně potvrzoval, což připouští i následující text J. Sadílka. Uvedené okno se nachází v konstrukci, která tvoří východní základové zdivo fary. Původně mělo jít o obvodové zdivo přesahující půdorys fary. Tečně přizděna je ke starší konstrukci věžovitého půdorysu, kterou J. Sadílek pokládá za součást severojižně orientované budovy, v níž vidí původní sídlo fundátora. Na základě již zmíněného okénka tak stlačuje dataci starší budovy hluboko k počátku 13. století. Délka středověké budovy severojižní rozměr fary přesahuje. Dokládá to její východní zed', která je zčásti přístupná ve sklepních prostorách nacházejících se východně od popisované středověké budovy. Její průběh zanechal otisky na později přistavěných zdech - v místě superpozic 


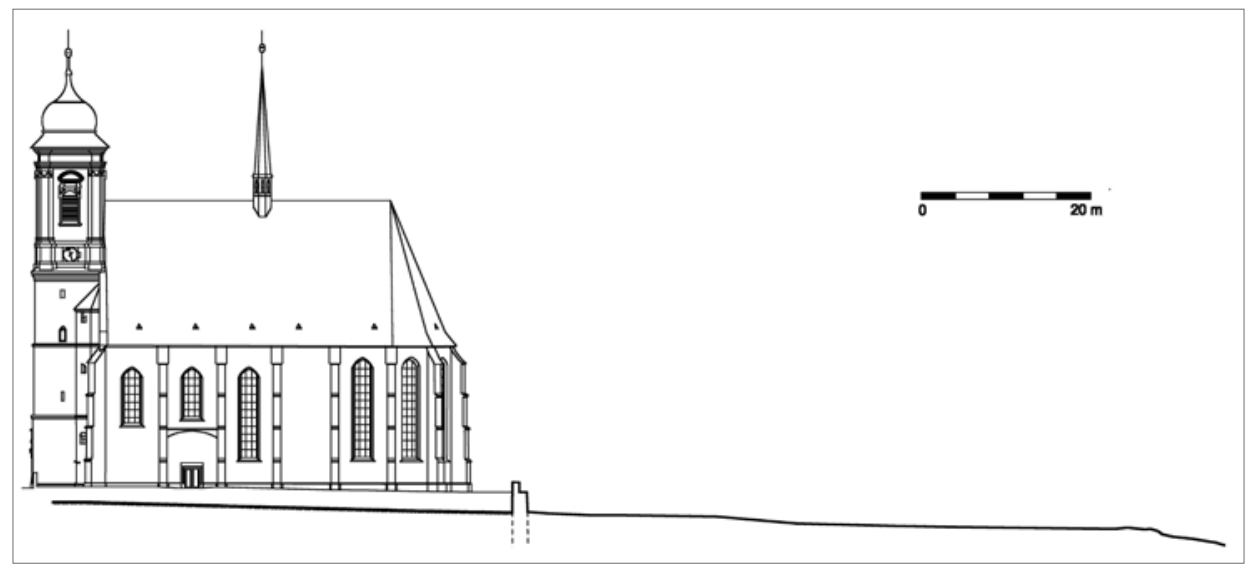

Obr. 4. Prủběh rostlého terénu zachyceného v sondě S24 a současného povrchu směrem k řece Svratce. Podle měření M. Prišt’ákové a Staněk 2014a, tab. 3, upraveno.

Abb. 4. Verlauf des in Sondierschnitt S24 erfassten, gewachsenen Geländes und der gegenwärtigen Geländeoberfläche in Richtung Flusslauf Svratka. Nach Vorlage der von M. Prišt’áková durchgeführten Vermessung und Staněk 2014a, Taf. 3, bearbeitet.

různě starých konstrukcí se vytvářejí statické trhliny. Průběh středověké zdi a rozsah př́ípadné budovy, se kterou souvisela, nejsou známy. Orientace a umístění východní zdi středověké budovy hypoteticky dovoluje připustit, že pokračovala mimo prostor fary v místech současné ohradní zdi kostela. Vazbu mezi těmito zdmi nejde v současné době posoudit (Sadílek 2010, 104-107).

\section{Výsledky výzkumů z let 2011 až 2013}

V letech 2011 až 2013 byly uskutečněny zabezpečovací práce kostela Povýšení sv. Kříže, které vyvolaly záchranný archeologický výzkum. ${ }^{1}$ Proběhla výstavba kanalizace (obr. 3), která má odvádět deštovou vodu a tím zabránit podmáčení základů kostela. Vzniklá situace dovolila pouze poodhalit složitý vývoj lokality, ale i tak učiněná pozorování přinesla řadu nových poznatků vztahujících se k podobě kláštera.

Geologické podloží vytvářelo mírné návrší, které se směrem na severovýchod a východ k řece Svratce svažovalo. V důsledku využivání sakrálního areálu došlo k postupnému zvýšení povrchu v některých místech až o $3 \mathrm{~m}$ oproti původnímu stavu (obr. 4). Nárůst terénu je dokumentován pro nejstarší etapu v souvislosti s výstavbou kláštera, kdy byl vnitřní areál konventu zarovnán do pochozí úrovně přemístěnými svahovinami a odpadními vrstvami. Během existence klášterních budov došlo $\mathrm{k}$ mírnému zvednutí komunikační úrovně v prostoru rajského dvora. Zaznamenán byl nárůst terénu i západně od konventních budov, především v souvislosti $\mathrm{s}$ výskytem náplavových vrstev pozdního středověku a raného novověku objevujících se v celém prostoru současné farní zahrady. Se zánikem klášterních budov a následnou výstavbou pozdně gotického chrámu pak bylo spojeno opětovné zvýšení terénu v okolí kostela Povýšení sv. Kříže, vymezené dnešní ohradní zdí hřbitova.

Při postupném budování jednotlivých větví kanalizace byly na několika místech odkryty zděné konstrukce, jež při vynesení do celkového plánu vytváří půdorys dispozičně odpovídající klášterní architektuře (obr. 5). Byly objeveny pozůstatky ambitu, který uzavíral někdejší rajský dvůr, a přilehlé části konventních budov. Z křížové chodby byly odkryty úseky zdí východní a severní části se třemi opěrnými pilíři (obr. 6 a 7). Dále byly dokumentovány západní a jižní stěny východního křídla konventu a jižní stěna s jihozápadním nárožím severního křídla. Západní konventní budova nebyla zachycena, nebot' se její základy nacházely pod novogotickou hrobkou

1 Záchranný archeologický výzkum byl zpracován v podobě nálezových zpráv (Staněk 2014; 2014a), které se staly podkladem pro diplomovou práci autora článku (Staněk 2014b). 


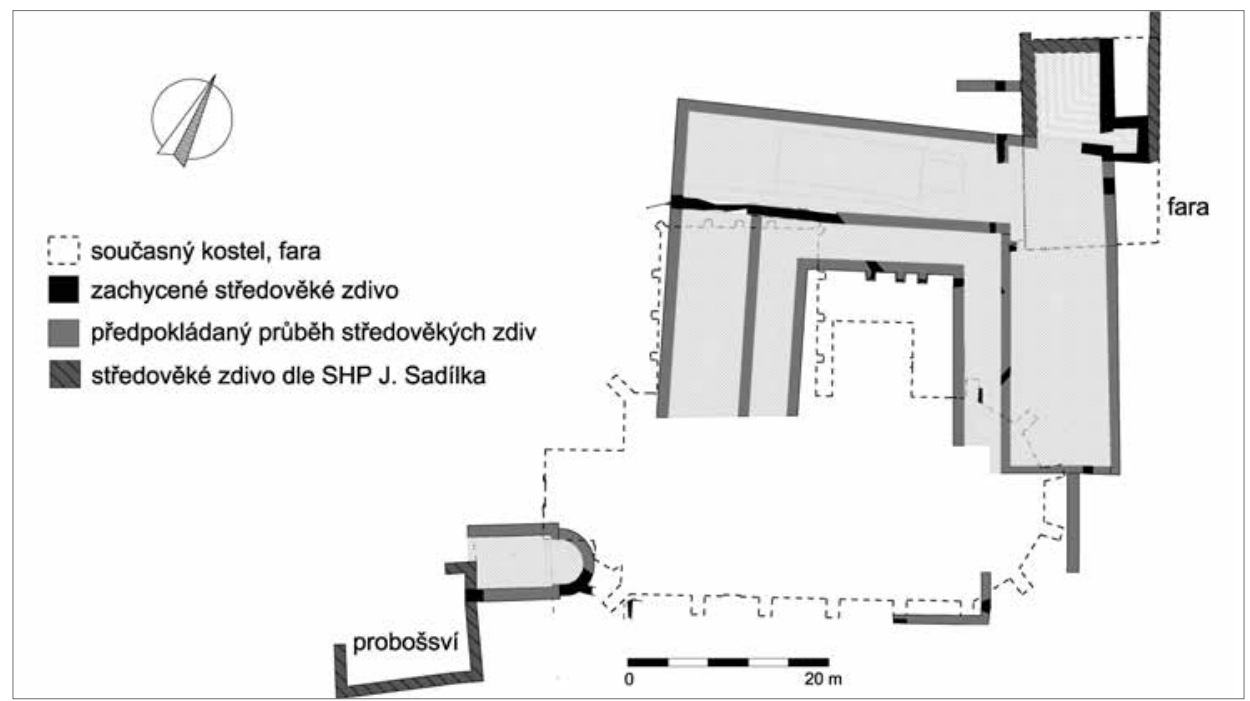

Obr. 5. Podoba církevního areálu na základě ZAV a s upravenými závěry SHP J. Sadílka. Podle Sadílek 2010; Staněk 2014b, 73, upraveno.

Abb. 5. Aussehen des Kirchenareals gemäß der Rettungsgrabung mit korrigierten Schlussfolgerungen der von J. Sadílek durchgeführten bauhistorischen Untersuchung. Nach Sadílek 2010; Staněk 2014b, 73, bearbeitet.

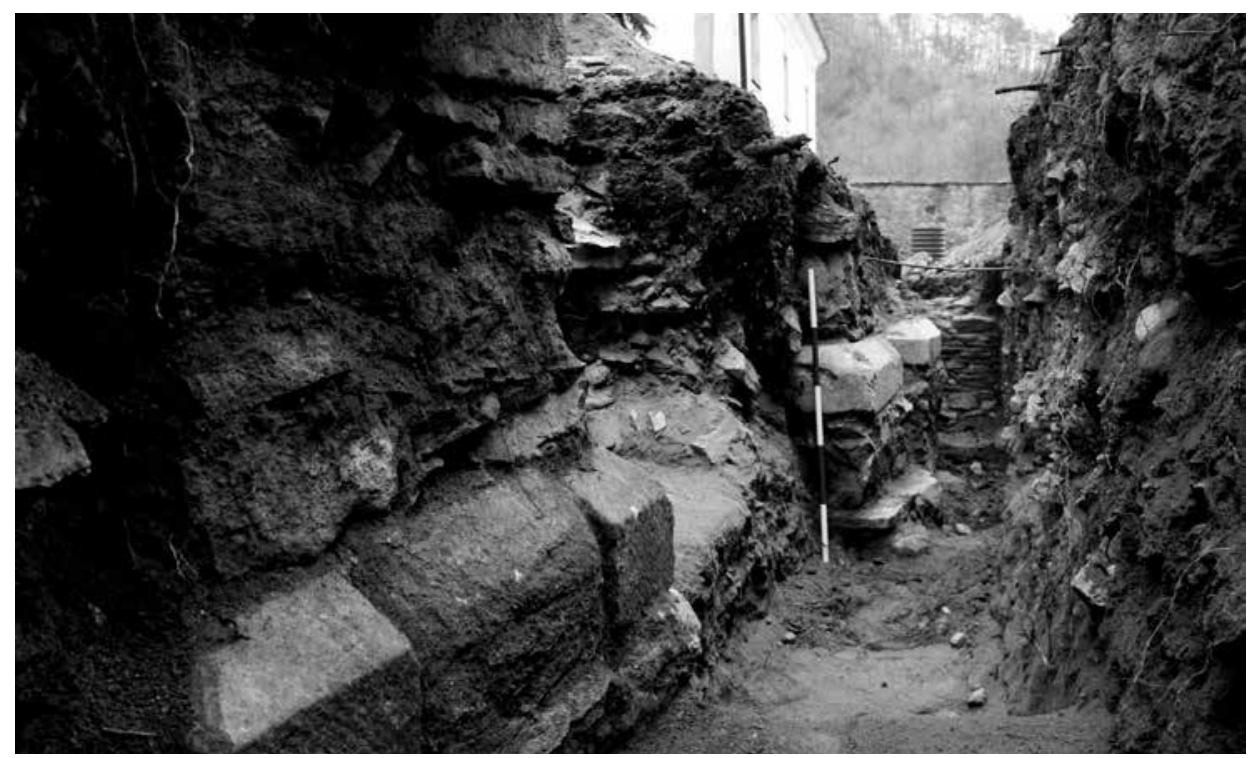

Obr. 6. Opěrné pilíře při severní zdi rajského dvora. Foto archiv Archaia Brno, o.p.s.

Abb. 6. Stützpfeiler an der Nordwand des Paradieshofes. Foto Archiv der gemeinnützigen Gesellschaft Archaia Brno.

rodu Mitrovských. Na její případnou existenci však v sondě S31 poukazoval náznak průběhu nároží s. j. 1903 i jižním směrem (obr. 8).

Jednotlivé konstrukce byly z obou stran lícovány. Tvořily je střední až velké bloky lomového kamene, vnitřní části byly vyplněny litým zdivem. Síla jednotlivých zdí klášterních staveb se pohybovala okolo $1,1 \mathrm{~m}$. Skladba hornin použitých k výstavbě konventu odpovídala geologické situaci blízkého okolí Doubravníka. Ten se nachází na styku dvou geologických jednotek, kde levý břeh řeky Svratky tvoří horniny moravika a pravý břeh svrateckého kristalinika (Demek et 


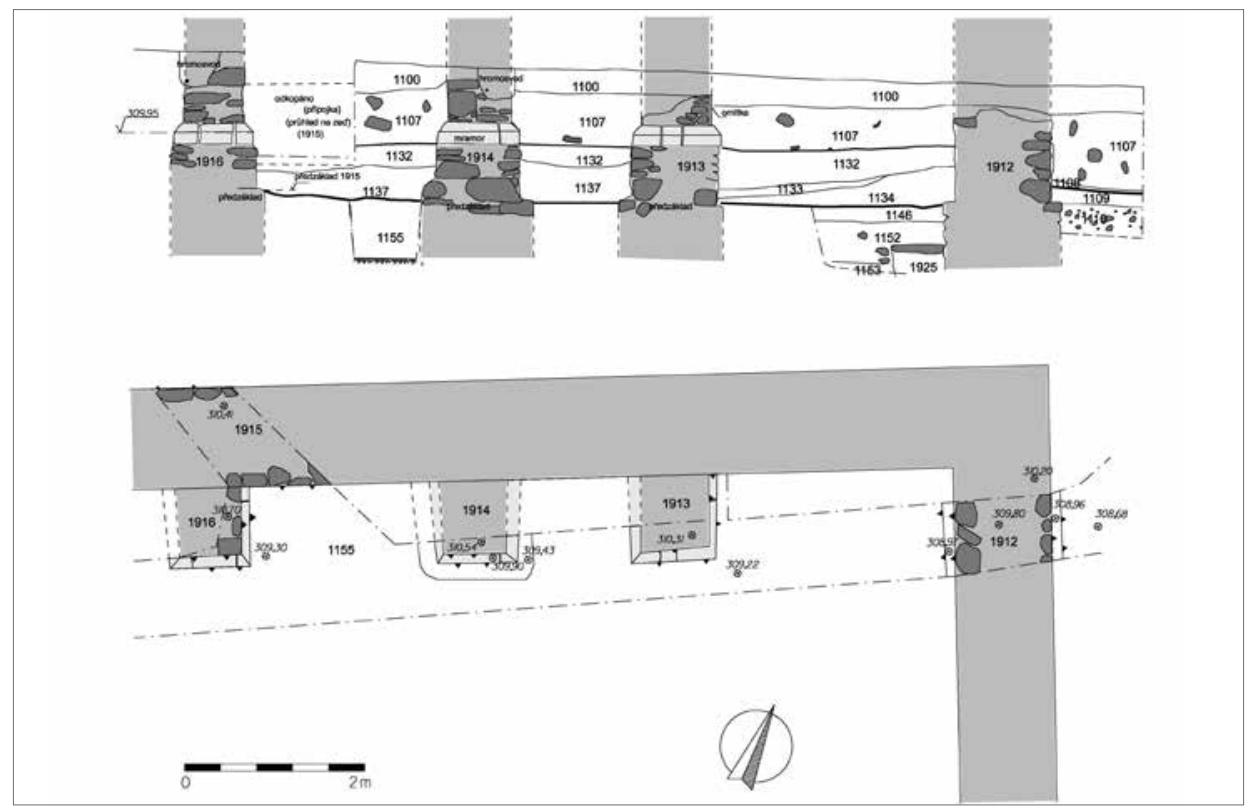

Obr. 7. Sonda S27 při severním konci rajské zahrady se třemi opěrnými pilí̌ri ambitu a tučně zvýrazněné pochozí úrovně. Podle Staněk 2014a, tab. 13, upraveno.

Abb. 7. Sondierschnitt S27 am nördlichen Ende des Paradiesgartens mit drei Stützpfeilern des Kreuzgangs und fett hervorgehobenem Gehniveau. Nach Staněk 2014a, Taf. 13, bearbeitet.

al. 1987, 81; Žížala-Vilímek 2011, 2). Vedle rul a pararul tak bylo jako stavebního materiálu užito svorů a amfibolitů. Na základě petrografického určení odebraných vzorků provedeného Janem Petříkem pocházel stavební materiál nejméně ze tří lokalit.

Nadzemní části zdí nesly na několika místech stopy po omítnutí. V místě styku zdí s pochozí úrovní se nacházel mírně odstupněný předzáklad. Základové zdivo bylo mnohdy pečlivě lícováno. To odráží skutečnost, že nejprve došlo k vybudování jednotlivých konstrukcí ve svažitém terénu a teprve následně k dosypání dorovnávek do pochozí úrovně konventu. Obdobná situace byla sledována např. při kostele dominikánského kláštera v Jihlavě. Základové zdivo dominikánského kostela bylo stavěno jako nadzemní a teprve po dostavbě bylo obsypáno do požadované úrovně (Dvořák et al. 1998, 305).

Tři dokumentované opěrné pilíře severního ambitu v sondě S27 nebyly vystavěny ve stejném rytmu a jemně symetricky (obr. 7). Vedle nestejných rozestupů šlo o rozdílnou výšku předzákladů, sílu zdiva i odlišný vzhled mramorových kamenických článků. Ve vzdálenosti 2,6m od východní zdi křížové chodby se nacházel východní pilír, rozestup mezi ním a prostředním pilířem činil $1,2 \mathrm{~m}$. Mezi prostředním a západním byla mezera $2 \mathrm{~m}$. U východního pilíre, stejně jako u východního kř́íla ambitu dosahovala výška předzákladu hodnoty $309,19 \mathrm{~m} \mathrm{n}$. m. Niveleta předzákladů dvou západních pilírů a zdi severního kř́́dla ambitu činí oproti tomu 309,33 m n.m. Rozdílná výška předzákladů byla kompenzována nestejně vysokými sokly jednotlivých pilírư od $0,49 \mathrm{~m}$ do $0,6 \mathrm{~m}$. Na ně dosedající patky se tudíž nacházely v rovině. Ke zhotovení zkosené patky pilíře byl použit nedvědický mramor. V př́ípadě patky západního pilíře šlo o velice hrubé provedení. Vlastní líc byl opět tvořen místním kamenem, jenž byl omítnut. Oproti soklům, jejichž šířka mírně překračovala $0,9 \mathrm{~m}$, byly dříky užší a jejich šiřka se pohybovala v rozmezí od $0,67 \mathrm{~m}$ do $0,78 \mathrm{~m}$.

Odkryty byly i základy zdiva, které mohly umístěním souviset s konventním kostelem. Šlo o konstrukci s. j. 1922 dokumentovanou v přípojce deštového svodu při jihovýchodním pilíŕi kostela (S23). Její průběh v okolních výkopech pro kanalizaci nebyl zachycen. Na její jižní stěnu 
se pravděpodobně narazilo v předstihové sondě $S 6$, kde byla v mělkém výkopu dokumentována jako předzáklad pilíře kostela. Absence nálezů či stratigrafických souvislostí znemožňuje přesnější stanovení doby vzniku popisované konstrukce. V rámci dispozice kláštera a potažmo konventního kostela mohlo jít o sakristii, kapli či příčnou lod' konventního kostela.

Mohutná destrukce tvořící západní profil sondy S21 poukazuje na východní konec presbyteria. Indikovat by jej mohl také spadlý blok zdiva s. j. $1920 \mathrm{v}$ této sondě. Závěr kostela by se tak nacházel značně východněji, než bylo naměřeno geofyzikálním průzkumem v roce 1992 (srovnej Hašek-Unger 1994, 38). Př́ípadná podoba presbyteria by tak mohla vycházet z požadavků na přísnou klauzuru Bohu zasvěcených žen a z početnosti konventu, který k roku 1410 čítal sedmnáct řeholnic (Foltýn et al. 2005, 286). Dalo by se tak tušit značně podlouhlé pravoúhlé presbyterium, které bylo obdobné u jiných augustiniánek, a to dominikánek (Jäggi 2006; Mezihoráková 2011). Bez dalších zpřesňujících informací se však i zde pohybujeme pouze v oblasti dohadů.

Při snaze o rekonstrukci podoby kláštera byly zohledněny i výsledky stavebně historického průzkumu Jaroslava Sadílka, a to především jím interpretovaného sídla majitele doubravnického újezdu (2010, 104-107). Blízkost této budovy dává tušit, že byla do dispozice kláštera nejpozději v době výstavby námi pozorované fáze konventu zahrnuta. Jak již bylo řečeno, J. Sadílek vyvozoval své závěry především na základě naměřených rozdílných šiřek zdí. Nelze tudíž vyloučit ani postupný vznik rozpoznané budovy. Hypoteticky můžeme předpokládat, že jde o ohrazení starší fáze církevního areálu s věžovitými obrannými prvky, přičemž jedna $\mathrm{z}$ těchto věží se dochovala $v$ reliktu jako součást sklepní prostory fary. Vztah mezi takovouto ohradní zdí, která je částečně př́stupná ze sklepa fary, a dodnes dochovanou ohradní zdí kostela nelze objasnit. Návaznost a shodná orientace naznačuje možnost původního průběhu až do současnosti (Sadílek 2010, 106). Postupným přebudováváním kláštera a jeho rozšiřováním tak mohlo dojít k zahrnutí části ohradní zdi do vlastního půdorysu konventu. V důsledku svažitého terénu a dorovnání vnitřních prostor se z původních místností parteru při ohradní zdi staly sklepní prostory. Koruna kamenné klenby jednoho sklepa byla dokumentována za presbytářem pozdně gotického kostela v sondě S21.

Dispozice konventu byla v ideálním případě obdélná, ve směru severozápad-jihovýchod o délce $31,5 \mathrm{~m}$ a severovýchod-jihozápad 43,5 m. Při severovýchodním rohu pak lze předpokládat rizalit vystupující více k severu. Obdobně vystupovala z kvadratického rozmístění konventu budova v nedalekém klášteře Porta coeli, v níž byly umístěny záchody (Belcredi 1993, 318).

Takto vymezený klášter by svou velikostí mírně překračoval rozsah obdobné šlechtické fundace v Dolních Kounicích (Konečný-Borský-Hořínek 1994, 265). Zároveň by však nedosahoval rozměrů zeměpanských založení, jakým byl např́íklad středověký panenský klášter v Předklášteří (Belcredi 1993, 318).

Odkryté části kláštera nepostihují jeho nejstarší podobu. V době výstavby dokumentovaných konstrukcí už uběhlo přinejmenším padesát let od jeho založení. Stratigrafie starších zdiv byla dokumentována pouze v sondě S31 (obr. 8), ve které byly odhaleny nejméně dvě starší stavební fáze. V př́ípadě konstrukce s. j. 1910 lze hovořit o vůbec nejstarším zachyceném zdivu, které hypoteticky můžeme dát do souvislosti s držitelem doubravnického újezdu. Oproti závěrům J. Sadílka, který předpokládané sídlo umist’uje do západní části fary, se námi pozorovaná budova nachází ve vyšší poloze vůči záplavové oblasti řeky Svratky. Současně ji také můžeme považovat za torzo první zděné stavby, kterou mohl konvent obdržet od zakladatele. Nahrazením uvedené budovy či přistavěním dalších konstrukcí pak vznikly dokumentované zdi s. j. 1904 a 1909. Bez odhalení nových skutečností nejsou však další závěry možné.

Velmi zajímavá situace byla zachycena při věži kostela v sondě S34 (Staněk 2014a, tab. 24-26). Byl zde odkryt půlkruhový zděný základ o vnitřním průměru 3,3 m (obr. 9). Malý rozměr stavby vylučuje variantu, že by mohlo jít o rotundu. Vzhledem k jejímu subtilnímu základu se také zdá být nepravděpodobné, že by odhalená konstrukce mohla být součástí nějakého neznámého fortifikačního prvku. Situace byla interpretována jako apsida kostela. Vzhledem k umístění stavby, která nepřiléhala ke kvadratuře a nebyla ani v její těsné blízkosti, můžeme nejspíše uvažovat o nejstarším doubravnickém kostele, který se zde nacházel nejpozději od 


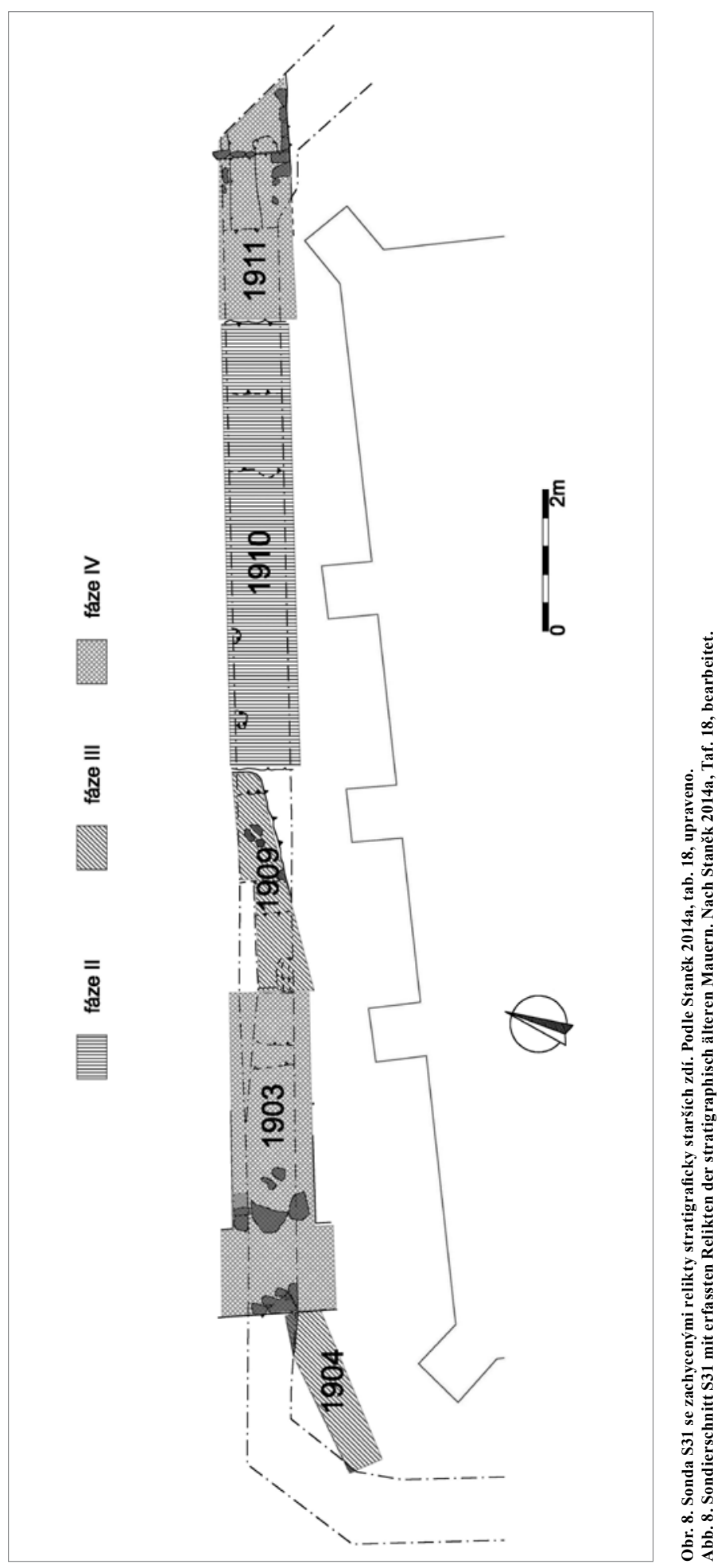


30. let 13. století a jenž byl podle dochovaných listin od papeže Řehoře IX. zasvěcen sv. Františkovi z Assisi (CDB III/1, 5-6 č. 8, 34-35 č. 35). Určité indicie k úvahám o dalším průběhu základu staršího kostelíka (?) a předpokládané vymezení jeho lodi nám poskytují pozorování na domě čp. 35. Podél opěrného pilíře, směřujícího do uličky před západním průčelím dnešního kostela, je na líci venkovní stěny dobře patrná výrazná statická trhlina. Za jejím vznikem může být existence staršího středověkého základu, na kterém byla později stěna domu čp. 35 částečně založena. Skutečný půdorys předpokládaného kostela může ověřit pouze další archeologický výzkum, popřípadě nové geofyzikální měření.

Doubravník představoval centrum osidlované oblasti. Dá se předpokládat, že nejpozději Štěpán z Medlova zde nechal pro své potřeby postavit dvorec s př́ilehlým kostelem. Analogicky rod pánů s erbem křídla v Tasově při osidlování Českomoravské vrchoviny založil dvorec s přilehlou rotundou (Unger-Kryl 2010, 110). Počátek doubravnického kostela tak nemusel souviset až se založením kláštera. Vznikající komunita Bohu zasvěcených žen pak mohla obdržet ke svým potřebám tento vlastnický kostel. Obdobná praxe předání staršího kostela je známa např́íklad při založení ženských cisterských klášterů v Pohledu či Sezemicích (Vlček et al. 1997, 433, 636; Kuthan 1983, 173-174). Společně s kostelem mohl konvent obdržet nějakou další budovu, která sloužila jako zázemí konventu (nabízí se alternativa s reliktem budovy zaznamenaným v sondě S31). Vzniklý církevní areál mohl být ohrazen v půdoryse, který se nám dochoval až do dnešních dnů a jehož relikty jsou př́istupny ve sklepení fary.

\section{Rozbor nalezených artefaktů}

Nejvíce nálezů bylo získáno z dorovnávek pochozí úrovně kláštera. Vypovídají tak nejvíce o době vzniku námi sledované fáze kláštera (výběr keramiky viz obr. 10). Celkem bylo hodnoceno 340 fragmentů z 279 jedinců o celkové hmotnosti $6779 \mathrm{~g}$. Fragmentarizace se pohybovala nejčastěji do velikosti $3 \times 3 \mathrm{~cm}(51 \%)$ a $6 \times 6 \mathrm{~cm}(33 \%)$. V keramické hmotě převažovala především příměs slídy, která nejenže se vyskytovala v ryze slídou ostřených nádobách $(29 \%)$, ale tvořila rovněž součást značného procenta tuhové keramiky, kde se vyskytovala asi jako přirozená součást keramického těsta a pouze v některých př́ipadech jako záměrné ostřivo. Obdobně se vyskytoval muskovit u keramických tříd s příměsí písku. Příměs tuhy se vyskytuje ve $42 \%$.

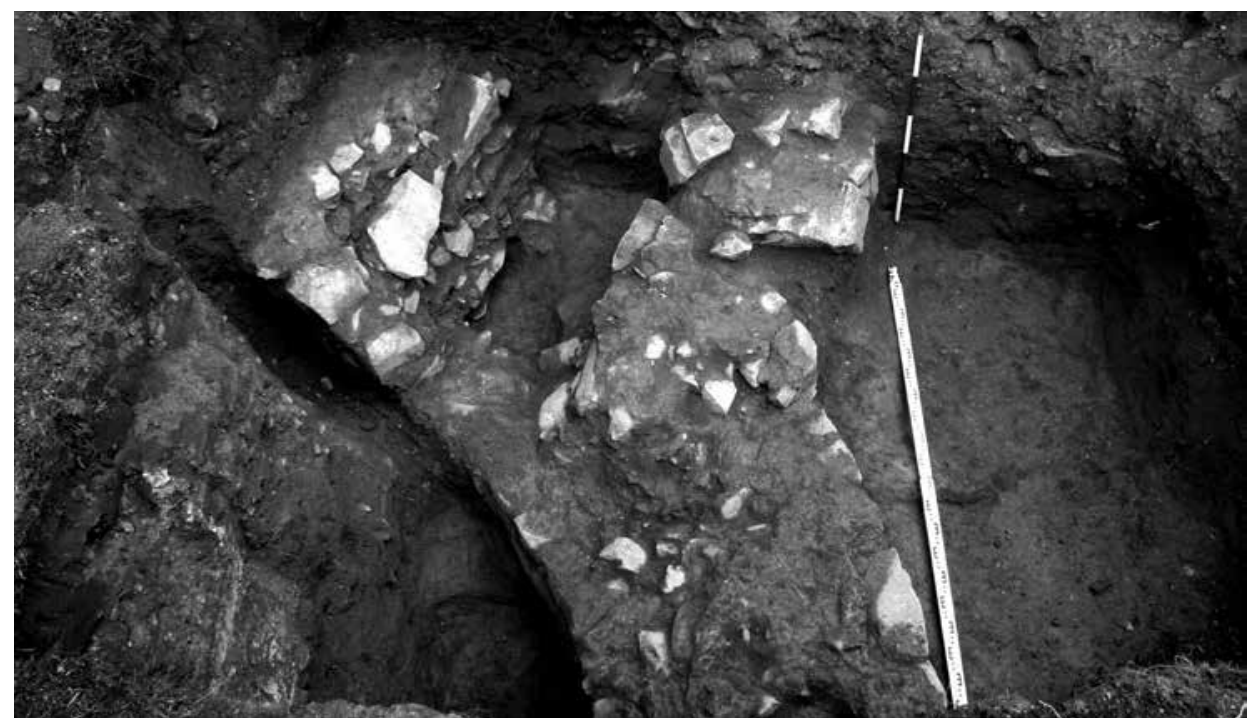

Obr. 9. Segment zachycené apsidy staršího kostela v sondě S34. Foto archiv Archaia Brno, o.p.s.

Abb. 9. Segment der in Sondierschnitt S34 erfassten Apsis der älteren Kirche. Foto Archiv der gemeinnützigen Gesellschaft Archaia Brno. 
Popisovaná skutečnost odpovídá vývoji keramických tříd pro oblast západní Moravy, kde přežívalo používání tuhové keramiky do pokročilého 13. století a jako přirozená součást keramické hmoty je sledováno zastoupení muskovitu (Zatloukal 1999, 198; Doležel-Sadílek 2004, 62-64; Procházka-Peška 2007, 173). Jednotlivý výskyt kvalitněji zhotovené keramiky, a to i okrově červené s úpravou vnitřního povrchu glazurou, může představovat mladší intruzi.

$Z$ druhového zastoupení nádob se nejčastěji vyskytly hrnce. Početněji více byly zastoupeny ještě zásobnice, zásobnicové hrnce či zvonovité a ploché poklice. Méně často šlo o fragmenty pocházející z kónických poklic, hrnců s uchem, mís a džbánů. Pouze po jednom exempláři pak byly zastoupeny pánev s jazykovitou rukojetí, třmenová konvice a pekáč.

Profilace okrajů se vyskytovala nejčastěji ve formě vzhůru vytažených, relativně hojně byl doložen okraj římsovitý. Starší formy okrajů byly zastoupeny okraji vzhůru vytaženými a vespod podžlabenými a okraji kuželovitými. Z nově nastupujících okrajů se vyskytly okraj směrem vzhůru zesílený, nepodžlabený a okraj střechovitý. Oba typy byly zastoupeny pouze po jednom jedinci. Třetina okrajů byla nezdobena. Mezi výzdobnými motivy se nejčastěji objevila vlnovka a ryté žlábky. Jeden okraj byl zdoben radélkem.

Z popisovaných výdutí hrnců byly dvě třetiny nezdobeny, nejčastější výzdobou plecí nádob byly ryté linie, v sedmi př́ipadech výzdoba ozubeným kolečkem $(9 \%)$. Vlnovka se vyskytla $\mathrm{v}$ pěti případech, kombinace vlnovky a žlábku $\mathrm{v}$ jednom př́ípadě.

Zjištěná skutečnost odpovídala podmínkám moravské části Českomoravské vrchoviny pro druhou polovinu 13. století, které byly sledovány na okolních hradech (Poláček 1990) či na důlním komplexu nedaleko Štěpánova (Doležel-Sadílek 2004, 58-65).

Do období 14. století, kdy byly sledované budovy využívány konventem, lze zařadit pouze uloženiny s. j. 169, 1141 a 1117. Jde o problematicky zachytitelné období, nebot' na většině sledovaných míst nedocházelo během využívání daného prostoru k nárůstu terénu. Na podlahové úrovně navazovaly destrukce se smíšeným keramickým materiálem. Ve zkoumaných souborech tak byla keramika zastoupena velmi sporadicky $(27 \mathrm{ks})$. Lze pozorovat převahu keramiky $\mathrm{s}$ př́měsí slídy a písečným ostřivem, téměř vymizela tuhová keramika. Zároveň se v souborech již ojediněle objevuje i vyspělá forma světle šedé písčité hladké keramiky, někdy označované jako boskovická, vyskytující se početněji právě v souborech severně od Brna (Procházka 1996, 331-333). Vedle okrajů vzhůru vytažených a římsovitých registrujeme i progresivní okraje střechovité. Výzdoba okrajů i těl hrnců se omezuje na ryté linie. Tvarové spektrum je v doubravnických souborech omezeno na hrnce, zvonovité poklice a nálevkovitou mísu s typickou výzdobou vlnovky na vnitřní straně. Dna stále nesou stopy po podsýpce.

Srovnávací materiál poskytují především soubory keramiky nalezené při průzkumu okolních opevněných sídel, např. Mitrov, Víckov, Olešničky, Pyšolec, Újezd u Tišnova (Poláček 1990, 417-419; 1990a, 227-228), a skupin keramiky 4-7 z důlního komplexu tratě Havírna (Doležel-Sadílek 2004, 64-65).

V průběhu 15. století došlo k zániku konventu, a tím i ke změně ve využívání sledovaného prostoru. Daná skutečnost se odráží ve zvýšeném počtu nalezených artefaktů v pochozích úrovních. Snad již v průběhu 15 . století dochází k terénním úpravám okolí kláštera. V bližším zázemí kláštera byly dokumentovány vrstvy naplavenin s keramikou z uvedeného období. Setkáváme se již s vyspělou vrcholně až pozdně středověkou produkcí, která je vedle stále užívané keramiky s příměsí slídy či písčitého ostřiva reprezentována především nově nastupující glazovanou hrnčinou (pro jižní Moravu se glazované užitkové nádoby objevují od druhé poloviny 14. století; Unger 1984, 294). Nepočetně byla v souborech zastoupena i leštěná keramika z jemného písku s kovově lesklým povrchem a bílým lomem. V rámci keramických tvarů se vedle nejvíce zastoupených hrnců častěji objevují džbány, zvonovité poklice, mísy a polévané trojnožky. V jednotlivých kusech jsou zastoupeny i tvary kahánku a pohárů. Srovnávací materiál poskytuje např. keramika získaná při výzkumu opevněné lokality Čepička u Předklášteří (Belcredi 1990) nebo z hradu Skály u Jimramova (Měŕínský 1980, 54-55; Endlicherová 2007).

Poslední skupinu získané keramiky tvoří soubor odpovídající vrstvám zániku a následného rozplanýrování klášterních budov. Vypovídací hodnota získaných archeologických artefaktů 


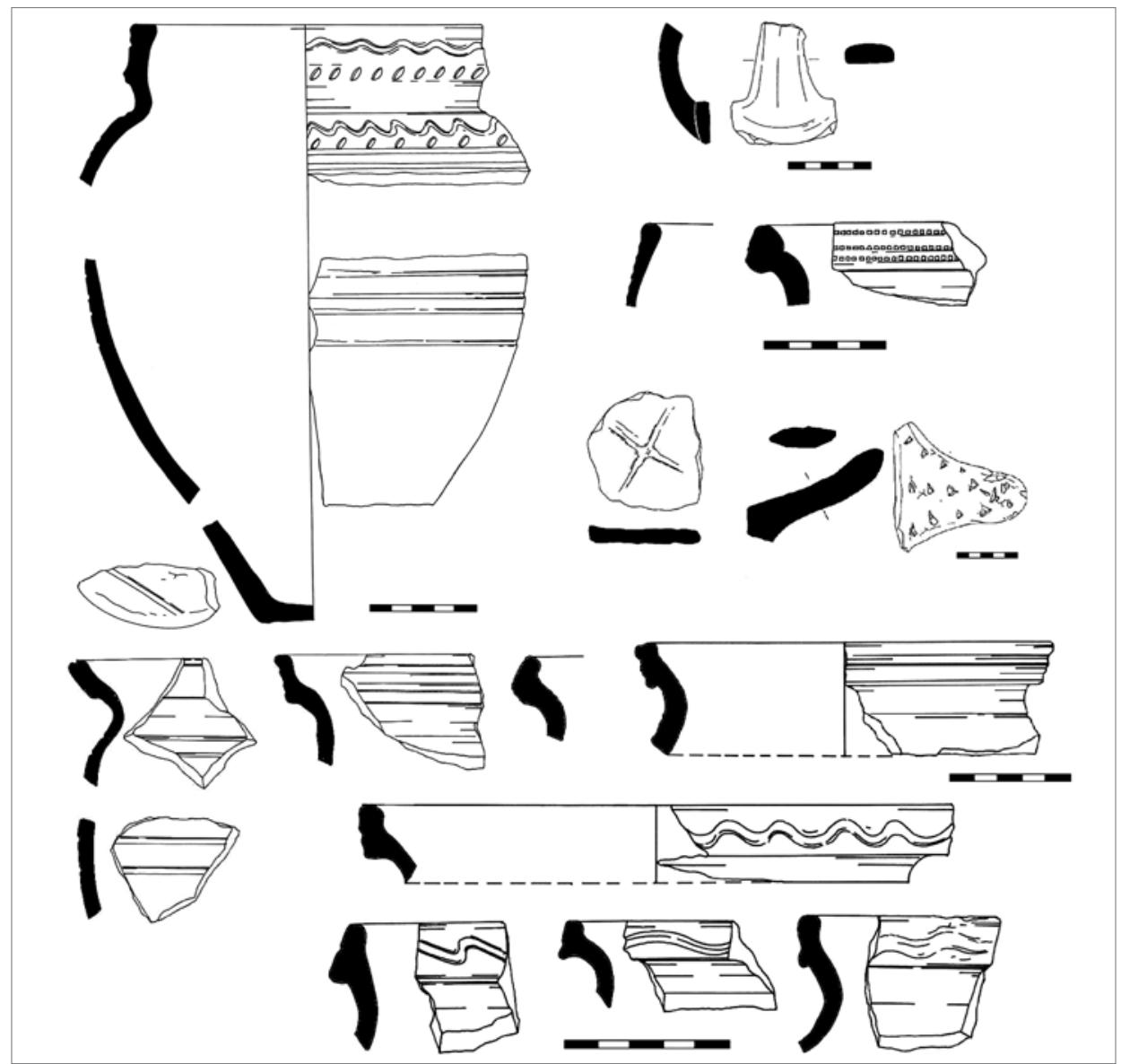

Obr. 10. Výběr keramiky ze sondy $S 17$ z dorovnávek pochozí úrovně kláštera. Kresba Š. Trávníčková.

Abb. 10. Aus den Nivellierschichten des Gehniveaus des Klosters stammende Keramikauswahl aus Sondierschnitt S17. Zeichnung Š. Trávníčková.

neposkytuje zcela jasnou odpověd’ na to, kdy k těmto událostem došlo. Vzhledem k absenci požárových vrstev lze předpokládat, že ke stržení budov došlo záměrně v souvislosti s chystanou či probíhající výstavbou dodnes stojícího chrámu Povýšení sv. Kř́̌že ve druhé a třetí čtvrtině 16. století. Z destrukce klášterních budov byl získán značně nesourodý a vzhledem k množství vytěžené zeminy nepočetný soubor keramiky. Získaný materiál obsahoval jak vrcholně středověkou keramiku (a to i zdobenou radélkem), tak keramiku tvarově a technologicky odpovídající 16. století. Nevyváženost keramického souboru je zapříčiněna především postdepozičními procesy.

\section{Závěr}

Archeologickým výzkumem při kostele Povýšení sv. Kř́iže v Doubravníku se podařilo doložit existenci dvou starších kostelů ze 13. století. Při západním průčelí byla zachycena apsida kostela, který umístěním neodpovídá rozvržení kláštera z druhé poloviny 13. století, položeného severně od dnešního chrámu. Lze se domnívat, že jde o kostel, který si zde nechal vystavět Štěpán z Medlova v první třetině 13. století. Po vzniku klášterní komunity kostel předal řádovým sestrám. Období jeho výstavby se nepodařilo stanovit. Intenzivní pohřbívání v mladších dobách 
zcela narušilo stratigrafii situací při odkryté apsidě a ani v nejbližším okolí se nedochoval sled středověkých vrstev, který by nám pomohl osvětlit dobu jeho vzniku. Nelze tedy zcela vyloučit ani možnost, že by mohlo jít o pozůstatky kostela sv. Kř́že známého z historických pramenů z poloviny 13. století. Archeologickým výzkumem byla nepřímo potvrzena i existence dalšího, již klášterního kostela, který vznikl nejdříve ve druhé polovině 13. století v souvislosti s výstavbou zkoumané klauzury. Tento druhý kostel se nacházel v místech dnešního chrámu Povýšení sv. Křiže, který také převzal orientaci (severovýchod-jihozápad) starší stavby. Výstavba chrámu v 16. století tedy přinejmenším respektovala starší stavbu, pokud na jejích základech nebyla i částečně postavena. Hypotetickou podobu přinesl v 90 . letech minulého století geomagnetický průzkum R. Haška a J. Ungera. Při současném archeologickém výzkumu došlo do určité míry ke zpochybnění naměřených výsledků (viz výše). Nově odhalené skutečnosti pouze indikovaly prŕpadný rozsah a hypoteticky i podobu konventního kostela.

Výzkum umožnil rámcově stanovit jednotlivé fáze vývoje osídlení a výstavby kláštera. Pozůstatky nejstarší zachycené aktivity (fáze I) náleží do druhé poloviny 12. století, nacházely se v místech pod zbořeným domem čp. 36. Pomineme-li základ apsidy kostela, který nemáme možnost archeologicky blíže datovat, byly nejstarší aktivity v prostoru zkoumaném v letech 2011 až 2013 zachyceny v sondě S31 (fáze II). Dokumentováno zde bylo zdivo s. j. 1910 o dochované délce $6,2 \mathrm{~m}$, nelze však říci nic bližšího o jeho funkci a době výstavby. Lze se jen dohadovat, že jde o pozůstatek sídla majitele doubravnického újezdu. Hypoteticky se toto sídlo mohlo nalézat případně i v místech současné fary, jak se domnívá J. Sadílek. Pro jeho umístění severně od hrobky Mitrovských by mohla svědčit i skutečnost, že se nachází ve vyvýšené poloze, a tudíž $\mathrm{v}$ bezpečí před př́ípadným zvednutím hladiny řeky Svratky. Její povodňové aktivity byly $\mathrm{v}$ rámci výzkumu doloženy v nižších polohách množstvím povodňových hlín, které pocházely jak z období středověku, tak i z novověkého období.

Další stavební etapa (fáze III), do které lze zařadit konstrukce s. j. 1909 a 1904, byla taktéž pozorována $\mathrm{v}$ sondě $\mathrm{S} 31$. Ani v tomto př́ípadě se vzhledem $\mathrm{k}$ rozsahu zachycených skutečností nelze jednoznačně přiklonit $\mathrm{k}$ tomu, o jakou formu stavby šlo a $\mathrm{k}$ jakým událostem by se časově dala vztáhnout. Mohlo jít o dílčí změny v rámci starší budovy s. j. 1910, nebo o budování prvotních prostor vznikajícího konventu. Obdobný charakter měly i zmíněné základy apsidy kostela s. j. 1919 v sondě S34. Lze-li ještě do této stavební fáze zasadit i vznik ohradní zdi s prrilehlou věžovou stavbou, která tvoři jižní sklep pod farou, nemůžeme s jistotou říci. Vztah ohradní zdi ke klášteru je nejasný, nevíme tedy, zda předcházela vzniku kláštera, nebo zda byla její výstavba vyvolána až v souvislosti s budováním kláštera.

Následná stavební etapa (fáze IV) je datována keramickým materiálem nacházejícím se v dorovnávkách kláštera, a to do druhé poloviny 13. století. Nejdříve v této době mohlo dojít k vybudování vlastního kláštera, který byl zcela nečekaně odhalen archeologickými výzkumy v letech 2011 až 2013. Jde prozatím nepochybně o největší přínos archeologie k poznání počátků kláštera.

Terén svažující se severovýchodním směrem byl v prostoru kvadratury dorovnán navážkami. Konvent byl pravděpodobně přistavěn ke stávající ohradní zdi, při níž vznikly suterénní prostory. Byla zachycena část obvodu klauzury, jejího severního a východního křídla, která uzavírala rajský dvůr o stranách ca $15 \mathrm{~m}$. Dvůr byl vymezen křížovou chodbou o šířce $3,7 \mathrm{~m}$. Opěráky při severní stěně rajského dvora svědčí o jejím sklenutí. Délka východního křídla mohla činit až 43 m a severního 44 m. Západní křrídlo nebylo odkryto, nebot' se nacházelo pod dnešní hrobkou Mitrovských.

Předchozí dvě fáze (III a IV) můžeme vztáhnout i k výrobní aktivitě ze 13. století, zachycené v prostoru domu čp. 36 .

Pro období vlastní existence kláštera ve 13. a 14. století nemáme z důvodu omezeného výzkumu prozatím k dispozici žádné soubory nálezů. Teprve v situacích od 15. století se vyskytuje odpadový materiál doprovázený keramickými fragmenty, což odpovídá i změně v nakládání s uvedenými prostory - postupné pustnutí konventu. Zánik budov nelze přesněji časově zasadit. Před výstavbou kláštera došlo ke značným terénním změnám v okolí kostela, kde byly doku- 
mentovány přinejmenším dvě fáze jeho navyšování. Jedna souvisela $\mathrm{s}$ úpravou terénu $\mathrm{v}$ době výstavby kostela, druhá pak vznikla až po jeho dostavbě.

Archeologickým výzkumem v letech 2011 až 2013 se podařilo zásadním způsobem doplnit nemnohé stávající poznatky o stavebním vývoji kláštera v Doubravníku a jeho historii. Zodpověděla se tak i jedna $z$ otázek souvisejících s klášterem, a to jeho lokalizace. Zároveň se ukázalo, že k úplnému odstranění kláštera nedošlo, ale že jeho značná část se nachází pod povrchem farní zahrady a kolem kostela. Pozorované reálie ve znovuobjevených konventních budovách lze případně rozšířit systematicky zaměřeným archeologickým výzkumem, který by na některých místech plošně odkryl skutečnosti, které se nám podařilo jen útržkovitě poodhalit.

\section{Prameny}

CDB II: Codex diplomaticus et epistolaris Regni Bohemiae. Tomus II. (Friedrich, G., ed.). Pragae 1912.

CDB III/1: Codex diplomaticus et epistolaris Regni Bohemiae. Tomi III. Fasciculus primus (Friedrich, G., ed.). Pragae 1942.

CDM II: Codex diplomaticus et epistolaris Moraviae. Tomus II. (Boček, A., ed.). Olomucii 1839.

CDM IX: Codex diplomaticus et epistolaris Moraviae. Tomus IX. (Brandl, V., ed.). Brünn 1875.

CDM XII: Codex diplomaticus et epistolaris Moraviae. Tomus XII. (Brandl, V., ed.). Brünn 1890.

RBM I: Regesta diplomatica nec non epistolaria Bohemiae et Moraviae I. (Erben, C. J., ed.). Pragae 1855.

\section{Literatura}

BELCREDI, L., 1990: Čepička - opevnění nad klášterem Porta Coeli v Tišnově-Předklášteří, ČMMZ 75, 99-122.

- 1993: Archeologický výzkum kaple svaté Kateřiny a areálu kláštera Porta coeli v Předklášteří u Tišnova Archäologische Erforschung der Kapelle der Hl. Katharina und des Klosters Porta Coeli in Předklášteří u Tišnova (Vorkloster bei Tischnowitz), AH 18, 315-341.

BOROVSKÝ, T., 2003: Kláštery, panovník a zakladatelé na středověké Moravě (14. a 15. století), rkp. disertační práce ulož. na FF MU.

DEMEK, J. et al., 1987: Hory a nížiny. Zeměpisný lexikon ČSR. Praha.

DOLEŽEL, J., 1996: Záchranné výzkumy ve středověkém jádře v Doubravníku, PV 1992, 68-72, tab. 22-24.

- 1998: Ante aream monasterii Sante Crucis - klášter v Doubravníku ve světle dosavadních výzkumů, Pravěk NŘ 8, 321-336.

DOLEŽEL, J.-SADÍLEK, J., 2004: Středověký důlní komplex v trati Havírna u Štěpánova nad Svratkou Mittelalterlicher Bergbaukomplex im Flurstück Havírna bei Štěpánov nad Svratkou. In: Těžba a zpracování drahých kovů: sídelní a technologické aspekty. Mediaevalia archaeologica 6 (Nováček, K., ed.), 43-101. Praha.

DVOŘÁK, J. et al., 1998: Výzkumy v dominikánském a minoritském klášteře v Jihlavě, Pravěk NŘ 8, 303-319.

ENDLICHEROVÁ, M., 2007: Keramické nálezy z budov č. 1 a 4 hradu Skály, rkp. diplomové práce ulož. na FF MU.

FOLTÝN, D. et al., 2005: Encyklopedie moravských a slezských klášterů. Praha.

HAŠEK, V.-UNGER, J., 1994: Archäogeophysikalische Prospektion der historischen unterirdischer Räume in der Tschechischen Republik, Der Erdstall - Hefte des arbeitskreises für Erdstallforschung 20, 30-43.

- 2001: Geofyzikální prospekce při archeologickém výzkumu hrobek a krypt. In: Ve službách archeologie II (Nekuda, R., ed.), 87-111. Brno.

CHAROUZ, J. Z., 1995: Doubravnické otazníky, ČMM CXIV, 365-373.

JÄGGI, C., 2006: Frauenklöster im Spätmittelalter. Die Kirchen der Klarissen und Dominikanerinnen im 13. und 14. Jahrhundert. Petersberg.

JAN, L., 1994: Premonstrátky nebo augustiniánky? (Opět k počátkům kláštera v Doubravníce), ČMM CXIII, 15-24.

- 1995: Ano, lze!, ČMM CXIV, 162-163. 
KONEČNÝ, L.-BORSKÝ, P.-HOŘÍNEK, J., 1994: K nejstarším stavebním dějinám kláštera Rosa coeli v Dolních Kounicích, JM 30, 264-273.

KUTHAN, J., 1983: Počátky a rozmach gotické architektury v Čechách. K problematice cisterciácké stavební tvorby. Praha.

MAZÁČ, L.-BUKAL, B., 1972: Doubravník. Doubravník: Místní národní výbor.

MĚŘíNSKÝ, Z., 1980: Morava za husitských válek ve světle archeologických nálezů a výzkumů - Mähren während der Hussitenkriege im Lichte der archäologischen Funde und Forschungen, AH 5, 31-68.

MEZIHORÁKOVÁ, K., 2011: Architektura středověkých kostelủ dominikánek v českých zemích v kontextu střední Evropy, rkp. disertační práce ulož. na FF UP.

NOVOTNÝ, B., 1958: Záchranný výzkum v Doubravníku u Tišnova, PV 1958, 99-100.

OHAREK, V., 1923: Vlastivěda moravská II. Místopis. Tišnovský okres. Brno.

PLAČEK, M., 1995: Rod erbu zubří hlavy do počátku 15. století (Pokus o genealogii moravského rodu), ČMM CXIV, 117-134.

POLÁČEK, L., 1990: Feudální sídla v povodí Bystřice, Nedvědičky a Bobrůvky ve světle archeologických nálezů. In: Pravěké a slovanské osídlení Moravy. Sborník k 80. narozeninám Josefa Poulíka (Nekuda, V., ed.), 407-425. Brno.

- 1990a: Újezd u Tišnova - „Hrádek“, AH 15, 223-233.

PROCHÁZKA, R., 1996: Brněnská stolní a kuchyňská keramika 2. poloviny 14. století - počátku 15. století, Pravěk NŘ 4, 323-344.

PROCHÁZKA, R.-PEŠKA, M., 2007: Základní rysy vývoje brněnské keramiky ve 12.-13./14. století, PV 48, 143-299.

SADÍLEK, J., 2008: Založení kláštera sv. Kř́iže, jeho trvání a zánik. In: Hrádek, M. et al., Doubravník 1208-2008, 63-89. Doubravník.

- 2010: Doubravník - kostel Povýšení svatého Křiže, farní areál, rkp. SHP, ulož. ve Farním úřadě v Doubravníku.

SEDLÁČEK, P., 1992: Páni z Medlova, JM 28, 37-55.

- 1995: Lze ženský klášter v Doubravníku jednou provždy považovat za augustiniánský?, ČMM CXIV, $159-161$.

- 1995a: Několik poznámek k rodokmenu Pernštejnů do 15. století, ČMM CXIV, 374-379.

STANĚK, P., 2014: Doubravník - Povýšení sv. Kř́že, NZ z A028/2011 ulož. v archivu Archaia Brno, o. p. s.

- 2014a: Doubravník - Povýšení sv. Křŕže, NZ z A139/2012 ulož. v archivu Archaia Brno, o.p. s.

- 2014b: Ženský klášter v Doubravníku, rkp. diplomové práce ulož. na FF MU.

ŠTARHA, I., 2003: Dvě rozdílná století doubravnického kláštera, SPFFBU C50, 31-52.

UNGER, J., 1984: Základní horizonty keramiky 12.-15. století na soutoku Jihlavy a Svratky, AR XXX, $288-296$.

UNGER, J.-KRYL, P., 2010: Archeologický výzkum a projekt prezentace románského kostela sv. Jiří v Tasově, Ochrana pamiatok 22, 107-113.

VLČEK, P. et al., 1997: Encyklopedie českých klášterů. Praha.

VODIČKA, J., 1951: Dva příspěvky k české diplomatice XIII. století, rkp. ulož. v Moravské zemské knihovně.

WOLNY, G., 1837: Die Markgrafschaft Mähren: topographish, statistisch und historisch geschildert. II. Band. Brünner Kreis. Brno.

ZATLOUKAL, R., 1999: Zpráva o archeologickém výzkumu ve Žd’áře nad Sázavou, trat' Staré Město, v letech 1996-1999 - Bericht über die archäologische Ausgrabung in Žd'ár nad Sázavou, Lage Staré Město, 1996-1999. In: Mediaevalia archaeologica 1 (Ježek, M.-Klápště, J., edd.), 193-207. Praha - Wrocław.

ZETTLER, A., 2006: Říšský klášter Reichenau a raně stř̌edověká benediktinská architektura. In: Svatý Prokop, Čechy a střední Evropa (Sommer, P., ed.), 50-63. Brno.

ŽÍŽALA, D.-VILÍMEK, V., 2011: Morfostrukturní analýza údolí Svratky v okolí Doubravníku, Informace České geologické správy 30, č. 1, 1-12.

\section{Zusammenfassung}

\section{Das Frauenkloster in Doubravník}

Zur Geschichte des Klosters von Doubravník existiert eine relativ erschöpfende Anzahl an erhaltenen Urkunden. Gleichwohl bleiben beträchtlich viele Fragen offen bzw. nur unzureichend 
geklärt. Eine dieser Fragen war bis vor kurzem die Lage des Klosters und die Anordnung der Klostergebäude. Durch die von der gemeinnützigen Gesellschaft Archaia Brno in den Jahren 2011 bis 2013 in der Umgebung der gotisch-renaissancezeitlichen Kreuzerhöhungskirche durchgeführten Grabungen konnte diese Frage teilweise beantwortet werden. Bei der Realisation der Regenwasserableitungen wurde an vielen Stellen mittelalterliches Mauerwerk dokumentiert, das mit dem sich dort seit dem 13. Jahrhundert befindenden Kirchenareal zusammenhing.

Doubravník wurde zum Tauschgegenstand zwischen Bischof Robert und Stefan von Medlov. Laut einer gefälschten mittelalterlichen Urkunde erfolgte dies im Jahr 1208. Stefan von Medlov war einer der Begründer der Macht des späteren Geschlechts von Pernstein am Oberlauf des Flusses Svratka. Der genannte Adelige gründete gegen Ende seines Lebens in Doubravník ein Frauenkloster von unbekannter Ordenszugehörigkeit. Das Gründungsdatum leitet sich vom Patrozinium des H1. Franziskus ab und wird in den Zeitraum der Jahre 1228-1231 gelegt. Nach den Hussitenkriegen wurde es aus wirtschaftlichen Gründen aufgelöst. Die durch Johann von Pernstein repräsentierte Gründerfamilie stellte sich auf die Seite der Hussiten, wodurch es zur Plünderung des Klosterbesitzes kam.

Durch die archäologische Grabung gelang es, für das 13. Jahrhundert die Existenz zweier Kirchen in Doubravník zu belegen. Man hat die Apsis einer Kirche entdeckt, deren Lage nicht der Anordnung des nördlich von der heutigen Kirche gelegenen Klosters aus der zweiten Hälfte des 13. Jahrhunderts entspricht. Vermutlich handelt es sich um eine Kirche, die Stefan von Medlov im ersten Drittel des 13. Jahrhunderts dort errichten ließ. Nach der Entstehung der Klostergemeinschaft übergab er die Kirche den Ordensschwestern. Der Zeitraum, in dem die Kirche gebaut wurde, konnte nicht bestimmt werden. Durch die in jüngster Zeit intensiv erfolgten Bestattungen war die stratigraphische Situation bei der freigelegten Apsis völlig gestört, und auch in der nächsten Umgebung blieb keine mittelalterliche Schichtenfolge erhalten, die Aufschlüsse über ihren Entstehungszeitraum liefern würde. Man kann demnach auch die Möglichkeit nicht ganz ausschließen, dass es sich dabei um Überreste der aus den historischen Quellen aus der Mitte des 13. Jahrhunderts bekannten Heiligkreuzkirche handeln könnte. Durch die archäologische Grabung wurde auch die Existenz einer weiteren Kirche indirekt bestätigt, bei der es sich bereits um die Klosterkirche handelte, die frühestens in der zweiten Hälfte des 13. Jahrhunderts im Zusammenhang mit dem Bau der untersuchten Klausur entstanden war. Diese zweite Kirche befand sich an der Stelle der heutigen Kreuzerhöhungskirche, die auch die Orientierung (Nordost-Südwest) des älteren Bauwerks übernommen hat. Beim Bau der Kirche im 16. Jahrhundert wurde das ältere Bauwerk demnach zumindest respektiert, falls sie nicht auch teilweise auf dessen Fundamenten errichtet wurde. Ein hypothetisches Aussehen lieferte in den neunziger Jahren des vergangenen Jahrhunderts die von R. Hašek und J. Unger durchgeführte geomagnetische Untersuchung.

Die Grabung ermöglichte eine grobe Bestimmung der einzelnen Entwicklungsphasen bezüglich Besiedelung und Errichtung des Klosters. Sieht man mal vom Fundament der sich archäologisch nicht näher bestimmbaren Kirchenapsis ab, wurden die ältesten Aktivitäten in dem 2011 bis 2013 untersuchten Bereich nordwestlich von der Gruft der Familie Mitrovský entdeckt. Dort wurde das Mauerwerk SE 1910 über eine erhalten gebliebene Länge von 6,2 m dokumentiert. Über Bau und Funktion des Mauerwerks lässt sich jedoch nichts Näheres sagen. Man kann nur vermuten, dass es sich um den Überrest des Gutshofs des Besitzers des Sprengels Doubravník handelt. Hypothetisch könnte sich dieser Gutshof - wie von J. Sadílek angenommen - eventuell auch an der Stelle des gegenwärtigen Pfarrhauses befunden haben. Für seine Lage nördlich der Mitrovský-Gruft könnte auch die Tatsache sprechen, dass er sich in erhöhter Lage befindet, d.h. in sicherem Abstand zu eventuellen Hochwasserständen der Svratka. Die Hochwasseraktivitäten dieses Flusses sind im Rahmen der Grabungen in den niedrigeren Lagen durch eine Fülle von sowohl aus dem Mittelalter, als auch aus der Neuzeit stammenden Hochwasserlehmen belegt worden.

Eine weitere Bauaktivität, der die Konstruktionen SE 1909 und 1904 zugeordnet werden können, wurde auch nordwestlich von der Mitrovský-Gruft beobachtet. Aber auch in diesem 
Fall lässt sich im Hinblick auf den Umfang der erfassten Tatsachen nicht eindeutig klären, zu welchen Ereignissen sie zeitlich Bezug nehmen könnte und um welche Bauwerksform es sich handelte. Ob um einzelne Veränderungen, die im Rahmen des älteren Gebäudes SE 1910 vorgenommen wurden, oder um die Errichtung der Primärräume des entstehenden Konvents, bleibt unklar. Einen ähnlichen Charakter hatten auch die erwähnten Fundamente der Kirchenapsis SE 1919. Ob sich auch die Entstehung der Einfriedungsmauer mit angrenzendem Turmbau, der den Südkeller unter dem Pfarrhaus bildet, in dieser Bauphase ansiedeln lässt, lässt sich nicht mit Sicherheit sagen. Der Bezug der Einfriedungsmauer zum Kloster ist unklar, wir wissen also nicht, ob sie vor der Entstehung des Klosters entstand, oder ob ihre Errichtung erst im Zusammenhang mit dem Bau des Klosters erfolgte.

Die anschließende Bauphase wird anhand des Keramikmaterials datiert, das sich in den Geländenivellierungen des Klosters befindet, und zwar in die zweite Hälfte des 13. Jahrhunderts. Frühestens in diesem Zeitraum konnte es zum Bau des eigentlichen Klosters gekommen sein, das durch die in den Jahren 2011 bis 2013 erfolgten archäologischen Grabungen völlig unerwartet entdeckt worden war. Was die Erkenntnisse bezüglich der Anfänge des Klosters betrifft, handelt es sich hierbei zweifellos um den größten Beitrag der Archäologie. Das nach Nordosten hin abschüssige Gelände wurde im Bereich des Kreuzgangs mit Aufschüttungen nivelliert. Das Konvent wurde wahrscheinlich an die bestehende Einfriedungsmauer angebaut, an welcher Kellerräume entstanden. Entdeckt wurden die Außenmauern des nördlichen und östlichen Teils der Klausur, die den Paradieshof umschlossen, dessen Seiten ungefähr $15 \mathrm{~m}$ betragen. Der Hof wurde von dem 3,7 m breiten Kreuzgang abgegrenzt. Die Stützpfeiler an der Nordwand des Paradieshofes deuten auf dessen Einwölbung hin. Die Länge des östlichen Konventgebäudes könnte bis zu $43 \mathrm{~m}$ und des nördlichen $44 \mathrm{~m}$ betragen haben. Das westliche Konventgebäude wurde nicht freigelegt, da es sich unter der heutigen Mitrovský-Gruft befindet.

Die letzten zwei Phasen können auch mit Produktionsaktivitäten in Verbindung gebracht werden, die im Bereich von Haus Nr. 36 entdeckt und von der archäologischen Grabung aus dem Jahr 1992 verzeichnet wurden.

Für die Zeit der eigentlichen Existenz des Klosters im 13. und 14. Jahrhunderts liegen uns wegen der nur begrenzt erfolgten Grabung vorerst keine Fundkomplexe vor. Erst in den Situationen ab dem 15. Jahrhundert kommt von Keramikfragmenten begleitetes Abfallmaterial vor, was auch dem veränderten Umgang mit den genannten Räumen entspricht, nachdem das Konvent nach und nach verwahrloste. Der Untergang der Gebäude lässt sich zeitlich nicht genau ansetzen. Vor dem Bau des Klosters war es in der Umgebung der Kirche zu beträchtlichen Geländeveränderungen gekommen, wo mindestens zwei Höherlegungsphasen dokumentiert wurden. Die eine hing mit der Herrichtung des Geländes während der Errichtung der Kirche zusammen, die zweite entstand dann erst nach ihrer Fertigstellung.

Durch die archäologische Grabung der Jahre 2011 bis 2013 ist es gelungen, die wenigen bisherigen Erkenntnisse über die bauliche Entwicklung des Klosters in Doubravník und seine Geschichte grundlegend zu ergänzen. So wurde auch eine der mit dem Kloster zusammenhängenden Fragen geklärt, und zwar was seine Lokalisierung betrifft. Gleichzeitig hat sich gezeigt, dass es nicht zu einer vollständigen Beseitigung des Klosters gekommen war, sondern dass sich ein beträchtlicher Teil der Anlage unter der Oberfläche des Pfarrgartens und um die Kirche herum befindet. Die beobachteten Realien in den neuentdeckten Konventgebäuden können gegebenenfalls durch eine systematisch angelegte archäologische Grabung erweitert werden, die an einigen Stellen die von uns nur in Ausschnitten enthüllten Tatsachen großflächig freilegen würden.

Mgr. Pavel Staněk, Archaia Brno, o.p.s., Bezručova 15, 60200 Brno, Česká republika, stanek@archaiabrno.cz 
